\title{
IF THE TIDE IS RISING, WHO PAYS FOR THE ARK?
}

\author{
Robert H. Cutting,* Lawrence B Cahoon, Jack C. Hall
}

\section{Introduction}

Two common goals of this meeting are to arrest the effects of sea level rise and other phenomena caused by Greenhouse Gases from anthropogenic sources ("GHG",) and to mitigate the effects. The fundamental questions are: (1) how to get there and (2) who should shoulder the cost? Given Washington gridlock, states, NGO's and citizens such as the Inupiat of the Village of Kivalina have turned to the courts for solutions. Current actions for public nuisance seek (1) to reduce and eventually eliminate GHG emissions, (2) damages for health effects and property damage_-plus hundreds of millions in dollars spent to prepare for the foregoing. The U.S. Court of Appeals just upheld the action against the generators of some $10 \%$ of the $\mathrm{CO}_{2}$ emissions from human activities in the U.S., clearing the way for a trial featuring the state of the art scientific linkage between GHG production and the effects of global warming. Climate change impacts on coastal regions manifest most prominently through sea level rise and its impacts: beach erosion, loss of private and public structures, relocation costs, loss of use and accompanying revenues (e.g. tourism), beach replenishment and armoring costs, impacts of flooding during high water events, and loss of tax base. Other effects may include enhanced storm frequency and intensity, increased insurance risks and costs, impacts to water supplies, fires and biological changes through invasions or local extinctions (IPCC AR4, 2007; Okmyung, et al., 2007).

\section{Why the Courts?}

Theoretically, courts can cut through the politics that clogs Congress and the legislatures because the public trial process can factualize the fictions using correct (not politicized) science and may be more resistant to influence (Johnson, 1989). Courts can then determine the real costs of using the airshed for waste disposal. Courts also have the power to review and upgrade the nature and extent of the common law, with wide latitude to adjust even accepted rights and responsibilities as modern science and social conditions require. Courts also have the power to fashion creative remedies, including supervision over time, damages, and remediation. Finally, courts also recognize and uphold our most strongly held values, which are embodied in the law.

Most of the current cases were initiated by states, NGOs and private parties during the Bush Administration because EPA denied both the phenomenon and that it had the legal authority to act, and it actively fought the states' efforts both to regulate and litigate. Bush left office with no GHG regulation in place even after the Supreme Court reaffirmed EPA authority to regulate (Massachusetts v. EPA). But the purposes of the lawsuits are more panoramic: the cases will first establish by a preponderance of evidence that GHG cause the alleged effects, and (1) impose equitable relief to prevent or at least manage GHG to minimize effects and damages; (2) seek to apportion liability among defendants and create a mechanism to allocate damages; then (3) secure compensation, including requirements for financial security (Cutting \& Cahoon, 2009).

Comprehensive regulatory action would likely be the most efficient mechanism. The Obama Administration has announced initiatives including increased research, GHG regulations and enforcement, plus support of major overhaul of the Toxic Substances Control Act. Climate change legislation may be gridlocked, but stakeholders have raised the issue of payment for air disposal capacity (rights to pollute). The key component that is missing from legislation is a reserve price that includes compensation to mitigate the externalities, like a true Green Tax (Zasloff, 2008); recent versions instead allocate free rights to pollute to "key" industries (usually historic polluters). Resale involves no payment to the public at all.

\section{States Lead Recovery Efforts}

State actions are fueled by the goal of managing GHG, but they are also driven by the very real costs for planning, emergency preparation and ultimately damages from loss of coastal environs, as well as the political advantage of acting to protect citizens and state resources. As with the tobacco litigation, this has caused the formation of a

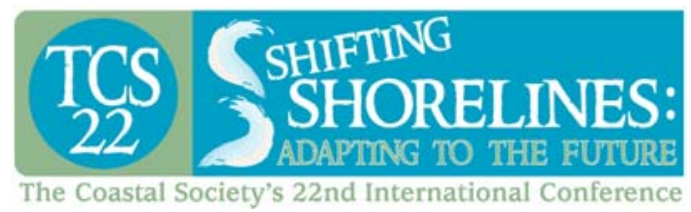


consortium to litigate and bring the resources of the state to bear on those responsible. These claims are joined in the Kivalina lawsuit with a claim that defendants carried on a disinformation campaign designed to conceal their knowledge of the real causation.

\section{The Cases}

Connecticut v. AEC (2009) focuses on key U.S. power generators. This action is grounded upon public nuisance, generally anything unreasonably injurious to the public. The actions allege that GHG produced by defendants unreasonably and adversely affect virtually the entire population through effects on water supply, as well as loss of entire coastal regions. The cases are proceeding to a trial that should feature a stellar cast of scientists to demonstrate the causal link. The Court of Appeals has already rejected defenses that included: (1) lack of justiciability (the power to solve the problem has been assigned by the Constitution to another branch of government), and (2) the federal common law is unavailable ("displacement"). The court found that (1) the courts in fact are the historic and proper forum for public nuisance determinations, and (2) the Clean Air Act is designed to regulate overall air quality, while public nuisance actions protect the population when regulatory measures fail to prevent damage. Thus the purposes are different and complementary. The Kivalina case (currently on appeal) alleges that the fossil fuel producers are the root cause of the problem that requires relocation and features a claim that the defendants used bogus science and disinformation to delay government intervention (Native Village Of Kivalina v. ExxonMobil). California filed against six motor vehicle manufacturers representing 6\% of U.S. anthropogenic $\mathrm{CO}_{2}$ emissions. Subsequently, the Obama Administration approved a package of California laws and regulations to control greenhouse gas emissions, particularly from motor vehicles. California thereafter dismissed its case because of those and other political developments and the possible negative procedural effects on the litigation (Alex, 2007; Zasloff, 2008).

\section{The Nuisance of Nuisance}

Public Nuisance cases have several problem areas. There are at least four balancing points where the court decides whether the defendant's conduct is reasonable, or the effect on the plaintiff(s) is "unreasonable", tests that were crafted imprecisely to allow the law to change over time to accommodate social, scientific and economic changes. Even if the conduct is held to be a nuisance, courts have recently reversed historic precedent to allow continuation by balancing considerations like tax base, jobs and the limitations of existing technology, effectively eliminating formerly automatic abatement and permitting private condemnation of other property. A further significant limitation is that public nuisances can be legalized by legislatures, although private actions cannot be eliminated without compensation, or an unconstitutional Taking has occurred (Richards v. Washington Terminal (1913); Rodgers, 2007).

\section{Thou Shalt Not Trespass}

We have previously proposed that the historic law of trespass, designed to protect private property interests, could be upgraded to redress the disconnect between science and law that began with the Industrial Revolution. Historically, and presently for visible trespass, any invasion of the three-dimensional space that is property constituted a wrong that could be proved objectively by spatial reference. Courts automatically awarded damages to deter violations (entry). That proved to be an inconvenient truth in a time when industry required free waste disposal into all available space (Rose, 1998), so the courts used sophistry to pretend that unseen materials did not enter and "trespass". The objective measure of trespass was replaced by the fuzzier notions of nuisance. The burden of discovery and prosecution under this more difficult standard falls on the receptors, and in any event the courts frequently found that industrial interests outweighed those of the small landowner or water rights holder (Green, 1997). Courts in the late $20^{\text {th }}$ Century finally had to concede that unseen materials actually do enter other properties, even if that could only be quantified by an equation (Borland, Bradley and Martin cases). Courts even recognized that any pollution-from a single car-would trigger a trespass and thereby end trans-boundary pollution. Thus to protect generators, the courts concocted another fiction: unseen pollutants are presumed harmless and permitted to trespass until proof of substantial injury. "Modern Trespass" thus outlaws harmless passage of a frisbee to protect property rights, but permits invasion by unseen materials that may cause serious damage over time until receptors discover the negative effects and, at their expense, prove substantial damages. Thus the population and all property

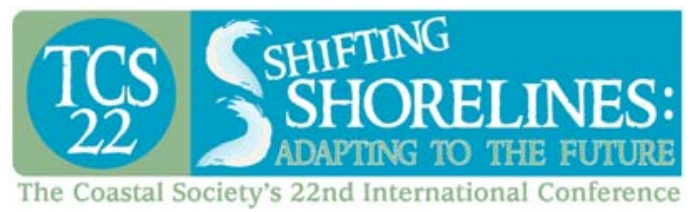


become test subjects in uncontrolled experiments on health, safety and property. Professor William Rodgers predicted in 2007: "As with nuisance, trespass will outlive its enemies. No lawmaking power on earth and no rumor-generating public relations campaign can long convince a human population that their bodies are fitting grounds for industrial experiments. With the bodies go the souls and in the two will be an army of determined skeptics." (Rodgers, 2007). Today, the policy considerations cut the opposite direction and dispel the fiction that unseen phenomena should be presumed harmless: (1) the potentially catastrophic effects of Global Warming are high priority because of the sheer magnitude of the public health and safety, economic and property damage concerns ; (2) an objective boundary-oriented test is more accurate scientifically and easier to manage, (3) the approach protects property interests that are far more numerous than the manageable number of sources, (4) there is a constitutional mandate both to contain emissions to avoid a "taking" of property, and to avoid making a "gift" of important public resources (Cutting, 2001, Cutting \& Cahoon, 2005, 2009).

\section{The Constitutional Dimension: Taking/Gift}

If the law does not effectively contain pollution at the generator's property boundaries, by definition, that material flows into public or private space. Government has deliberately permitted GHG emissions (even under proposed regulations), which triggers two levels of consequence:

(1) Private Property: U.S. Supreme Court cases such as Loretto v. Manhattan Teleprompter (1982) reaffirmed that any physical intrusion assisted or permitted by government can constitute a Taking of Private Property under the Fifth Amendment, thus government becomes liable in addition to the generator, a huge consequence. Size does not matter - cable boxes and telegraph lines are sufficient, nor does it matter that the intrusion is temporary or intermittent (artillery shells, flight below $500 \mathrm{ft}$ ). With GHG there is no question that there is invasion: the question under the current common law is whether it is reasonable or significant. Under the constitutional analysis, like historic trespass, the only question is whether the invasion is occurring.

(2) Public Property: The Airsheds: We and Professor Gerald Torres argue that the Public Trust Doctrine provides another basis to impose the requirement of review and compensation on both government and generators. Scholars argue that air should be protected as surface water is, and that enormous value has been given to generators to pollute Public Trust resources without any accounting or compensation (Sax, 1970, 1993;Torres, 2002; Dunning, 2005). This is something of a mirror image of the trespass analysis. If government facilitates invasion into private property, it is a Taking; when that invasion occurs to public property, government has transferred valuable waste disposal rights and sacrificed other public uses without value. U.S. Supreme Court authority holds that public resources cannot be subordinated to a commercial interest without (1) a finding of Public Purpose, and (2) fair compensation for the value to the polluter and the diminution of public rights. Professor Torres proposes Skytrusts as a governmental or quasi-governmental mechanism to value and allocate rights to pollute, and to provide a forum to determine damages. Professor Torres notes that the price for the right to pollute might not be sufficient if it does not include all externalities from generation of GHG (effectively a true "green tax": see Zasloff, 2008). It will be impossible adequately to price either the waste disposal value or the effects on public and private interests without significant additional research funding, for example (Cutting \& Cahoon, 2005). While the Code of Justinian included air, Anglo-American law has not, except in the context of avigation (U.S. v. Causby). The Supreme Court in 1946 imposed on all property a Public Trust easement for avigation over about 500 feet. The majority of airspace is thus either publicly owned or held subject to a Public Trust avigation easement, so the state can claim either trespass into public property or interference with the Public Trust interests. Practically, though, private property owners still own "to the heavens" (subject to avigation rights), hence it would seem that the private right of action for trespass/Taking would be available as well, thus avoiding any deficiencies in the public trust argument.

\section{Remedies}

Using property boundaries to contain emissions internalizes externalities directly. A trespass case could result in: (1) creative mechanisms to implement solutions over time (e.g., environmental review, remediation, gradual reductions) to end the trespass, much as courts have done in nuisance cases (Boomer v. Atlantic Cement Co.); (2) damages to date as well as provision for future damages by insurance or bonding. "Taking" claims make

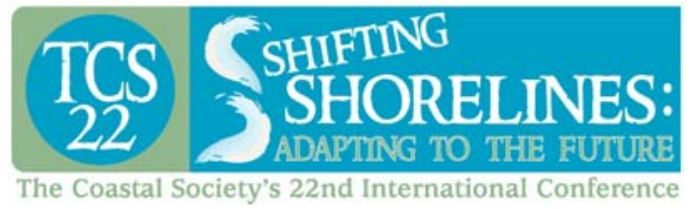


government liable for all the above plus more. Government could attempt condemnation, but that too should include the costs of all negative externalities and would require a finding of public purpose to use the airsheds for waste disposal. Even under the wide latitude of the "Wal-Mart" case (Kelo v. City of New London), that might prove difficult, especially when continued exposure of the population is contemplated. Permitting legislation like the Clean Air Act could actually be held unconstitutional if it imposes collective Taking without effective remedy. (U.S. v. Causby (1946), Bormann v. Bd. Of Supervisors (1998); Gerald Torres, (2002). If the statutes were voided, replacement legislation could easily provide a mechanism to discover, mitigate and compensate the effects (Cutting \& Cahoon, 2009). Legislation that attempted to interfere with the property rights would also run afoul of the Fifth Amendment.

The remedy is nearly identical for public property: (1) there must be a finding of Public Purpose, a process that would focus attention on the issue of emissions, and (2) there must be fair value paid including present and future damages. The statutes could be declared unconstitutional for interference with the Public Trust, or the grant of emissions rights voided (Ill. Cent. R.R. v. Illinois, 1892).

\section{The Effects of Containment}

These concepts mesh with two overarching sets of principles. The first set is the true Free Market Economy. The predicted effects of Global Warming constitute "externalities" that must be included in the price (internalized) or there is a fundamental market failure (Verhoef, 1999). Restraining pollutants at the generator's property lines literally forces internalization by eliminating external effects. Generators maintain that will increase prices, thus consumer behavior could be influenced because alternative products and services could be more accurately priced and compared once the government pollution subsidy is removed from the equation (CEQ, 1970). If temporary pollution were permitted, good science would be required to analyze the real costs. Either generators should be required to shoulder the research and development (as with pharmaceuticals and California fisheries), or the public could transparently award research funds to private and educational institutions with results available to all.

The second is the Collision of the Transformative Economy with the Economy of Nature. The Economy of Nature is a reflection of scientific understanding of natural systems. The Transformative Economy, on the other hand, values the "highest and best use" of property, regardless of effects on the Economy of Nature (Sax,1993). Any coastal wetland, for example, might over time generate more revenue if a high-rise is built and would therefore be preferred by the Transformative Economy. Much of the conflict stems from the modern focus on the rights of landowners and property lines. Property lines and political boundaries do not conform to the natural law of airsheds and watersheds, of course, but they can provide an objective mark for materials discharged from generator property. Wastes that are contained on private property will not likely impact public and private resources elsewhere. This is true for all pollutants, not just GHG.

There are additional potential benefits: (a) Improved Knowledge of Short Term and Long-Term Effects: Research will be required of those who temporarily hold a right to pollute that will provide long overdue necessary data. Public debate can then occur as to whether public moneys should be committed to the enterprise and the scientific community will be in a much better position to assist the policy decisions. (b) Economic Stimulus: The economic effect cannot be ignored: Research and technological advances to minimize pollutants will prime the pump for many purposes: retrofitting, technological solutions, especially green energy- and transportation -related, two major contributors to GHG. (Friedman 2008; Jones 2008; Speth, 2008) That research could stimulate more creativity in many domains, much as the space program spun off inventions (CEQ, 1972). Since the earth is the only space vehicle that can hold us all, the need is clear. (c) The Precautionary Principle would be implemented instead of, "Use the Citizens as Unknowing Test Subjects then make it hard for them to get medical care and sue".

\section{The International Context}

While U.S. reduction of GHG would likely be viewed favorably internationally, firms doing business in the U.S. could have more incentive to move offshore. While a full discussion is beyond the scope of this summary, we cannot ignore the conclusion that trade pacts must be modified to permit nations to limit access to their markets for entities that operate under less-stringent environmental regulations. Firms that cut costs by polluting are engaged in

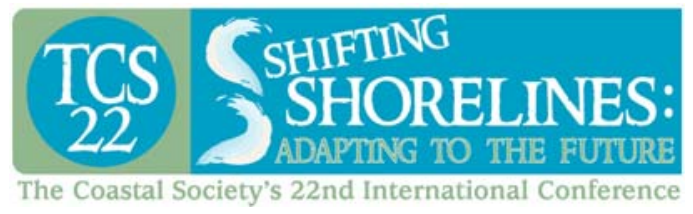


an unfair trade practice that externalizes those costs in ways that are harmful to the global environment and therefore public health while undercutting firms that comply. We join many other voices to advocate renegotiation of the trade treaties to make evasion of market nations' standards an unfair trade practice and to permit imposition of a Green Tax that fairly prices the externalities (Cutting \& Cahoon, 2005, 2009; Goldman, 1992).

\section{Conclusion}

The popular and scientific support for imposition of accountability and responsibility on the generator to counterbalance the rights enjoyed during the Industrial Revolution is substantial. There is no question that the common law actions can assist in protecting the coasts, as well as shifting the risks to those that cause the damages.

\section{References}

Cutting, R.H. 2001, One Man’s Ceilin’ Is Another Man’s Floor: Property Rights As The Double-Edged Sword, 31 ENVTL. L. 819 (2001);

Cutting, R.H. \& Cahoon, Lawrence B., The Gift that Keeps on Giving: Global Warming Meets the Common Law 10 VJEL 111 (2009) http://www.vjel.org/journal.php?vol=2008-2009;

Cutting, R.H. \& Cahoon, Lawrence B. (Spring 2005). Thinking Outside the Box: Property Rights as a Key to Environmental Protection, 22 Pace Envt'l L. Rev pp 55; 64-67

Rodgers, William (2007). in Creative Common Law Strategies for Protecting the Environment, pp. 77-90 ELI, Washington DC, Rechtschaffen \& Antolini eds.

Torres, Gerald, (2002) Who Owns the Sky? 19 Pace Envtl. L. Rev. 515,

Rose, Carol M. (1998). The Several Futures of Property: Of Cyberspace and Folk Tales, Emission Trade and Ecosystems, 83 MinN. L. REV. 129, 137

Sax, Joseph L. (1993). Property Rights and the Economy of Nature: Understanding Lucas v. South Carolina Coastal Council, 45 Stan. L. Rev. 1433, 1442

Robert H. Cutting

UNC Wilmington

Dept. of Environmental Studies

601 S. College Road

Wilmington, NC 28403-5949

$\mathrm{Ph}$ (910) 231.9622

Facs (910) 962.7634

cuttingr@uncw.edu 